\title{
Distribution of Area, Production and Productivity of Maize in Different Districts of Northern Hills of Chhattisgarh, India
}

\author{
Pradeep Kumar Ganjeer* , Durgesh Sagar, V. Mishra and M.L. Lakhera \\ Indira Gandhi Krishi Vishwavidyalaya, Raipur 492012, Chhattisgarh, India \\ *Corresponding author
}

\section{A B S T R A C T}

\begin{tabular}{|l|}
\hline K e y w o r d s \\
Area, Production, \\
$\begin{array}{l}\text { Productivity, Maize, } \\
\text { Compound growth rate, } \\
\text { Trend analysis etc. }\end{array}$ \\
\hline Article Info \\
\hline $\begin{array}{l}\text { Accepted: } \\
\text { 12 July 2018 } \\
\text { Available Online: } \\
\text { 10 August 2018 }\end{array}$ \\
\hline
\end{tabular}

\section{Introduction}

Maize is a cereal crop which is cultivated widely throughout the world and has the highest production among all the cereals. It is an important food staple in many countries and is also used in animal feed and many industrial applications. The crop has tremendous genetic variability, which enables it to thrive in tropical, subtropical, and temperate climates.

Global production of maize has grown at a calculated annual growth rate (CAGR) of 3.4 per cent over the last ten years, from 717 million metric tons (MnMT) in 2004-05 to 967 MnMT in 2013-14. Maize is grown throughout the year in India. It is predominantly a kharif crop with 85 per cent of the area under cultivation in the season. Maize is the third most important cereal crop in India after rice and wheat. It accounts for $\sim 9$ per cent of total food grain production in the country.

Maize production in India has grown at a CAGR of 5.5 per cent over the last ten years from 14 MnMT in 2004-05 to $23 \mathrm{MnMT}$ in 2013-14. During 2009-10 there was a decline in production primarily due to drought that affected production of kharif crops in the country. The area under maize cultivation in the period has increased at a CAGR of 2.5 per cent from 7.5 Mn hectare in 2004-05 to 9.4 Mn hectare in 2013-14, the remaining increase in production is due to increase in yield (India 
Maize Summit, 2014). Chhattisgarh is a state in Central India, which came into existence as a State on November 1, 2000. With a geographical area of 137.90 lakh ha which is $4.15 \%$ of the country and net sown area of 46.77 lakh ha which is $35 \%$ of its geographical area. The Northern hills of Chhattisgarh region comprises of Sarguja, Jashpur, Koriya, Balrampur and Surajpur. Agriculture is counted as the chief economic occupation of the state. The main crops are rice, maize and other small millets and pulses; oilseeds, such as groundnut, soybean and sunflower, are also grown. Rice is the staple diet - quite logical in the area proudly called the 'rice bowl of India' by locals. The total geographical area of Northern Hills zone is 28.47 lakh ha which is 21 percent of total area of the State while the net sown area is 8.35 lakh ha (National conference on rabi campaign C.G., Sept. 2012).

In order to get a good idea of how the production of crop has varied over the years, it is necessary to study its trend over the years. In order to assess pattern of area, production, productivity along a considerable span of time to provide indicators to the planners of the State, the present investigation was carried out with the following objectives:

To assess the growth rate in area, production and productivity of the Maize Crop in different Districts of Northern Hills of Chhattisgarh.

To assess the level of influence contributed by area and productivity towards production of Maize Crop in different Districts of Northern Hills of Chhattisgarh.

\section{Materials and Methods}

The study was confined to the Northern Hills of Chhattisgarh state and its districts. After the resettlement of district now there are three districts in Northern Hill zone, namely; Sarguja, Koriya and Jashpur.

The time series secondary data on area, production and productivity of maize were collected for the Period from 1979-80 to 201213 from various issues of publication such as 'Agricultural Statistics' published by Directorate of Agriculture, Government of MP, Bhopal and 'Basic Agricultural Statistics' published by Commissioner of Land Records and Settlement Gwalior, Government of MP and from the website www.agridept.cg.gov.in and "Table of Agriculture Statistics" (201213) published by Commissioner, Land Records and Settlement, Raipur, CG.

The entire period has been divided into three periods to assess the trend analysis (linear, quadratic and exponential trends) as shown below:

Pre-establishment of IGKV, Raipur: 1979-80 to $1986-87$ (Period- I).

Post-establishment of IGKV, Raipur and preperiod of M.P. and C.G. partition: 1987-88 to 1997-98 (Period-II).

Post-period of M.P. and C.G. partition: 199899 to 2012-13 (Period-III).

The main consideration underlying the choice of these sub-periods was based on the fact that 'Indira Gandhi Krishi Vishwavidyalaya' and newly formed State Chhattisgarh started functioning from the year 1987-88 and 199899 respectively and number of districts is different in different study period.

In order to quantify the growth of area, production and productivity of maize crop, district wise trend in area, production and productivity were worked out for maize crop of Northern Hills of Chhattisgarh, for the three separate periods. To analyse the trend in area, 
production and productivity of maize crop, the following different functional forms were fitted.

Linear function $-\mathrm{Y}=\mathrm{a}+\mathrm{bx}$

Quadratic function - $Y=a+b x+c x^{2}$

Exponential function $-\mathrm{Y}=\mathrm{a} \cdot \mathrm{b}^{\mathrm{x}}$

Where,

$\mathrm{Y}=$ Area, production and productivity of maize crop

$\mathrm{x}=$ Time variable

The functional form having the highest coefficient of determination $\left(\mathrm{R}^{2}\right)$ is selected for fitting the trend. Similarly, the growth rate of area, production and productivity of maize crop were also computed.

Compound Growth Rate was also computed for area, production and productivity of maize crop based on the exponential function for the period. The Compound Growth Rate was computed as follows:

Exponential trend equation: $\mathrm{Y}=\mathrm{a} \cdot \mathrm{b}^{\mathrm{x}}$

Where, $\mathrm{x}$ is the time variable, $\mathrm{Y}$ is the variable for which growth rate is calculated and $b$ is the regression coefficient of $\mathrm{Y}$ on $\mathrm{x}$.

Compound Growth percentage $(\mathrm{CGR} \%)=(\mathrm{b}-$ 1) $\times 100$

To measure the magnitude of variability in area, production and productivity the coefficient of variation (\%) was computed.

Further the instability index was also calculated to examine the instability area, production and productivity of maize crop in different districts of Northern Hills of Chhattisgarh over the time period by using the formula:
Instability Index $(\mathrm{I})=\left(1-\mathrm{R}^{2}\right) \times \mathrm{CV}^{2}$

The effect of area, productivity and their interaction towards increasing production were worked out by using the following formula. Similar technique was also employed by Cavery (1991); Sharma and Kalita (2004); Dhakre and Sharma (2010); Das and Sharma (2012) and Sharma (2012).

(Change in Production) $\Delta \mathrm{P}=\mathrm{Y}_{0} \Delta \mathrm{A}+\mathrm{A}_{0} \Delta \mathrm{Y}$ $+\Delta \mathrm{A} \Delta \mathrm{Y}$

Where,

(Change in Area) $\Delta \mathrm{A}=\mathrm{A}_{\mathrm{n}}-\mathrm{A}_{0}$

(Change in Yield) $\Delta \mathrm{Y}=\mathrm{Y}_{\mathrm{n}}-\mathrm{Y}_{0}$

$\mathrm{A}_{0}, \mathrm{P}_{0}$ and $\mathrm{Y}_{0}$ represent the area, production and productivity in the base year and $A_{n}, P_{n}$ and $Y_{n}$ the corresponding area, production and productivity in the current year. The first, second and third on the right side of above equation represent area, productivity and interaction effect, respectively.

\section{Results and Discussion}

The results obtained after fitting the three functional forms are presented in the Table 1. These were compared using $\mathrm{R}^{2}$ and the best fitted model is presented in the paper. The higher $\mathrm{R}^{2}$ showing function for maize crop is presented hereunder.

Table 1 shows that the $\mathrm{R}^{2}$ values of quadratic function for area, production and productivity for maize crop in Northern Hills are higher than linear and exponential functions in most of the cases. Though $\mathrm{R}^{2}$ for quadratic function showed the best fit but in some cases the regression coefficients were not found significant. Hence in those cases the linear or exponential function as the regression coefficient showed significant effect was considered for forecasting the trend in area, 
production and productivity of maize crop in Northern Hills of Chhattisgarh.

Table 2 reveals that the ' $c$ ' value in the quadratic functional forms for area, production and productivity were some negative impact on maize crop in Northern Hills of Chhattisgarh over the periods-I, II III. This implies the acceleration of decline in area, production and productivity of maize (Table 3).

The growth of production and productivity of maize crop were declined over the periods. This assumption seemed to be positive from the Table 4, where significant compound growth rates were recorded for the growth in area, production and productivity of maize crops during the periods under study. The area of maize crop shows negative growth rate due to decline in area over the time periods and shifting of area to other commercial/remunerative crops.

The co-efficient of variation in area, production and productivity of maize crop are worked out for the periods from 1979-80 to 2012-13 and presented in Table 4. It reveals that growing of maize crop is not risky in Northern Hills of Chhattisgarh since it has lower coefficient of variation (less than 24.81 per cent).

The results of the instability indices in case of area, production and productivity of maize crop in the Northern Hill zone are positive which also indicate lower risk for continuing/growing of crop in future too (Table 4).

Table. $1 \mathrm{R}^{2}$ value of linear, quadratic and exponential function for maize crop

\begin{tabular}{|c|c|c|c|c|c|}
\hline \multirow[t]{2}{*}{ Districts } & \multirow[t]{2}{*}{ Periods } & \multirow[t]{2}{*}{ Aspects } & \multicolumn{3}{|c|}{ Model fitted ( $\mathbf{R}^{2}$ obtained) } \\
\hline & & & Linear & Quadratic & Exponential \\
\hline \multirow[t]{9}{*}{ Sarguja } & \multirow[t]{3}{*}{ I } & Area & 0.9800 & 0.9811 & 0.9815 \\
\hline & & Production & 0.0205 & 0.4457 & 0.0189 \\
\hline & & Yield & 0.0000 & 0.4351 & 0.0014 \\
\hline & \multirow[t]{3}{*}{ II } & Area & 0.2360 & 0.3875 & 0.2391 \\
\hline & & Production & 0.0149 & 0.0313 & 0.0244 \\
\hline & & Yield & 0.0060 & 0.0404 & 0.0152 \\
\hline & \multirow[t]{3}{*}{ III } & Area & 0.0066 & $0.0398^{\#}$ & 0.0052 \\
\hline & & Production & 0.1019 & $0.4392^{\#}$ & 0.0842 \\
\hline & & Yield & 0.1071 & 0.4460 & 0.0898 \\
\hline \multirow[t]{3}{*}{ Koriya } & \multirow[t]{3}{*}{ III } & Area & 0.0555 & $0.7682^{\#}$ & 0.0561 \\
\hline & & Production & 0.0480 & $0.5111^{\#}$ & 0.0416 \\
\hline & & Yield & 0.0549 & 0.5891 & 0.0481 \\
\hline \multirow[t]{3}{*}{ Jashpur } & \multirow[t]{3}{*}{ III } & Area & 0.9030 & 0.9137 & $0.9020^{\#}$ \\
\hline & & Production & 0.0005 & $0.2148^{\#}$ & 0.0041 \\
\hline & & Yield & 0.1026 & 0.2874 & 0.1003 \\
\hline
\end{tabular}


Int.J.Curr.Microbiol.App.Sci (2018) 7(8): 2434-2441

Table.2 Result of fitted trend for maize crop

\begin{tabular}{|c|c|c|c|c|c|c|}
\hline Period & Districts & Aspects & Equation & a & b & c \\
\hline \multirow[t]{3}{*}{ I } & \multirow[t]{3}{*}{ Sarguja } & A & Exponential & 40.3588 & 1.0157 & - \\
\hline & & $P$ & Quadratic & 20.8356 & 13.1584 & -1.3941 \\
\hline & & Y & Quadratic & 556.4643 & 282.3333 & -31.3810 \\
\hline \multirow[t]{3}{*}{ II } & \multirow[t]{3}{*}{ Sarguja } & A & Quadratic & 45.4734 & 0.4415 & -0.0519 \\
\hline & & $\mathrm{P}$ & Quadratic & 58.7958 & -2.5690 & 0.1753 \\
\hline & & $\mathrm{Y}$ & Quadratic & 1299.2242 & -70.9853 & 5.3904 \\
\hline \multirow[t]{9}{*}{ III } & \multirow[t]{3}{*}{ Sarguja } & A & Quadratic & 37.0990 & -0.1102 & 0.0077 \\
\hline & & $P$ & Quadratic & 61.9052 & -5.9460 & 0.4280 \\
\hline & & Y & Quadratic & 1685.1597 & -163.2482 & 11.7939 \\
\hline & \multirow[t]{3}{*}{ Koriya } & A & Quadratic & 7.9360 & 0.1456 & -0.0098 \\
\hline & & $\mathrm{P}$ & Quadratic & 13.6816 & -1.1895 & 0.0806 \\
\hline & & Y & Quadratic & 1711.3115 & -167.5507 & 11.3447 \\
\hline & \multirow[t]{3}{*}{ Jashpur } & A & Exponential & 6.8379 & 0.9892 & - \\
\hline & & $P$ & Quadratic & 11.3830 & -0.7028 & 0.0444 \\
\hline & & Y & Quadratic & 1654.8372 & -87.0096 & 6.6222 \\
\hline
\end{tabular}

Note: $\mathrm{A}=$ Area, $\mathrm{P}=$ Production, $\mathrm{Y}=\mathrm{Y}$ ield/Productivity

Table.3 Forecasted area and production for maize crop

\begin{tabular}{|l|l|r|r|r|r|r|r|}
\hline Districts & Aspects & \multicolumn{7}{|c|}{ Years } \\
\cline { 2 - 10 } & & $2013-14$ & $\mathrm{CI} \pm$ & $2014-15$ & $\mathrm{CI} \pm$ & $2015-16$ & $\mathrm{CI} \pm$ \\
\hline \multirow{2}{*}{ Sarguja } & Area & 37.31 & 0.42 & 37.45 & 0.40 & 37.61 & 0.38 \\
\cline { 2 - 10 } & Production & 76.34 & 5.52 & 84.52 & 5.32 & 93.55 & 5.14 \\
\hline \multirow{2}{*}{ Koriya } & Area & 7.76 & 0.06 & 7.58 & 0.05 & 7.38 & 0.05 \\
\cline { 2 - 10 } & Production & 15.28 & 0.83 & 16.75 & 0.79 & 18.39 & 0.77 \\
\hline Jashpur & Area & 5.75 & 0.17 & 5.69 & 0.16 & 5.62 & 0.16 \\
\hline & Production & 11.51 & 0.85 & 12.27 & 0.82 & 13.12 & 0.79 \\
\hline
\end{tabular}


Table.4 Compound growth rate (\%), co-efficient of variation (\%) and instability index of area, production and productivity of maize crop

\begin{tabular}{|c|c|c|c|c|c|}
\hline Period & Districts & Aspects & CGR (\%) & CV $(\%)$ & Instability Index \\
\hline \multirow[t]{3}{*}{ I } & \multirow{3}{*}{ Sarguja } & A & $1.57 * * *$ & 3.59 & 0.000 \\
\hline & & $\mathrm{P}$ & $1.24^{\mathrm{NS}}$ & 22.01 & 0.048 \\
\hline & & Y & $-0.33^{\mathrm{NS}}$ & 21.23 & 0.045 \\
\hline \multirow[t]{3}{*}{ II } & \multirow{3}{*}{ Sarguja } & A & $-0.40^{\mathrm{NS}}$ & 2.57 & 0.000 \\
\hline & & $\mathrm{P}$ & $-1.57^{\mathrm{NS}}$ & 23.48 & 0.054 \\
\hline & & Y & $-1.18^{\mathrm{NS}}$ & 22.90 & 0.052 \\
\hline \multirow[t]{9}{*}{ III } & \multirow[t]{3}{*}{ Sarguja } & A & $0.03^{\mathrm{NS}}$ & 1.91 & 0.000 \\
\hline & & $\mathrm{P}$ & $1.93^{\mathrm{NS}}$ & 24.58 & 0.055 \\
\hline & & Y & $2.02^{\mathrm{NS}}$ & 24.81 & 0.056 \\
\hline & \multirow[t]{3}{*}{ Koriya } & A & $-0.13^{\mathrm{NS}}$ & 2.31 & 0.000 \\
\hline & & $\mathrm{P}$ & $0.91^{\mathrm{NS}}$ & 18.14 & 0.032 \\
\hline & & Y & $1.05^{\mathrm{NS}}$ & 19.67 & 0.037 \\
\hline & \multirow[t]{3}{*}{ Jashpur } & A & $-1.08 * * *$ & 4.97 & 0.000 \\
\hline & & $\mathrm{P}$ & $0.27^{\mathrm{NS}}$ & 16.87 & 0.028 \\
\hline & & Y & $1.37^{\mathrm{NS}}$ & 16.96 & 0.026 \\
\hline
\end{tabular}

Table.5 Effect of area, productivity and their interaction on production of maize crop in different districts of Northern Hills of Chhattisgarh

\begin{tabular}{|c|c|c|c|c|c|}
\hline District & Period & $\begin{array}{l}\text { Differential } \\
\text { Production } \\
(\Delta \mathbf{P})\end{array}$ & $\begin{array}{c}\text { Area } \\
\text { effect } \\
\left(\mathbf{Y}_{0} \Delta \mathbf{A}\right)\end{array}$ & $\begin{array}{c}\text { Productivit } \\
\text { y effect } \\
\left(\mathbf{A}_{0} \Delta Y\right)\end{array}$ & $\begin{array}{c}\text { Interactio } \\
n \\
(\Delta \mathbf{A} \Delta \mathbf{Y})\end{array}$ \\
\hline \multirow[t]{3}{*}{ Sarguja } & I & -2081.2 & $\begin{array}{r}3762.5 \\
(180.8)\end{array}$ & $\begin{array}{r}-5289 \\
(-254.1)\end{array}$ & $\begin{array}{l}-554.7 \\
(-26.7)\end{array}$ \\
\hline & II & -820.3 & $\begin{array}{r}-1662 \\
(-202.6)\end{array}$ & $\begin{array}{r}870.2 \\
(106.1)\end{array}$ & $\begin{array}{l}-28.5 \\
(-3.5)\end{array}$ \\
\hline & III & 23209.6 & $\begin{array}{r}3407.8 \\
(14.7)\end{array}$ & $\begin{array}{r}18673.2 \\
(80.4)\end{array}$ & $\begin{array}{r}1128.6 \\
(4.9)\end{array}$ \\
\hline Koriya & III & 2105.64 & $\begin{array}{r}-123.92 \\
(-5.9)\end{array}$ & $\begin{array}{r}2251.8 \\
(106.9)\end{array}$ & $\begin{array}{r}-22.24 \\
(-1.0)\end{array}$ \\
\hline Jashpur & III & 1486.65 & $\begin{array}{r}-1083.75 \\
(-72.9)\end{array}$ & $\begin{array}{r}2894.4 \\
(194.7)\end{array}$ & $\begin{array}{r}-324 \\
(-21.8)\end{array}$ \\
\hline
\end{tabular}

The relative effect of contributions of area, productivity and their interactions on increased production of maize crop in
Northern Hills for the periods from 1979-80 to $1986-87 ; 1987-88$ to $1997-98$ and $1998-99$ to 2012-13 have been estimated (Table 5). It 
reveals that the production of the maize crop in Northern Hills has exhibited an increasing trend. This increase in production was due to increase in area as well as interactions of area and productivity of maize crop during the period under review. The interaction of area and productivity in period-I (1979-80 to 1986-87) and period-II (1987-88 to 1997-98) has exhibited a declining trend, whereas the entire period was positive.

It is highlighted from the above discussion that the growth in area, production and productivity for maize crop in Northern Hills are positive and statistically significant. The coefficients of variation for maize crop are less than 24.81 per cent which indicates that less risk is involved in cultivation of maize crop during the period under review. The lower value of instability indices also strengthens this fact. The production and productivity of the maize crop have increased during the period under review due to the combine effects of area and productivity. Therefore, the productivity can be further increased by adopting appropriate technologies. In light of these findings, following suggestions are recommended for formation of appropriate policies.

It is a general observation that growth in productivity of crop is skimpy because of poor availability of HYV seeds, widespread infestation of pest and diseases, destruction of crops by wild animals, inadequate and irregular water supply etc. Therefore, steps should be taken to overcome these difficulties faced by the cultivators at the field level.

A rising growth trend associated with high degree of variability is a sign of vulnerability in the growth process. Wide spread ups and downs in area, production and yield of crop shatters the rational expectations of the cultivators and leads to many disruptive consequences. Thus, there is an urgent need for formation of proper policies and implementation of programmes in order to increase the production and yield of crop. Introduction of HYVs in the nontraditional areas as well as dissemination of appropriate technologies through training is call for the day.

\section{References}

Anonymous, 1979-1998. Agricultural Statistics, Directorate of Agriculture, Government of Madhya Pradesh, Bhopal.

Anonymous, 1979-1998. Basic Agricultural Statistics, Commissioner of Land Records and Settlement, Gwalior, Madhya Pradesh.

Anonymous, 2012-13. Table of Agriculture Statistics. Commissioner, Land Records and Settlement, Raipur, Chhattisgarh.

Cavery, R. 1991. Groundnut Production in Tamilnadu - A Decomposition Analysis. Agricul Situation in India, 46: 319-321.

Das, K. K. and Sharma, A. 2012. Growth and variability in Area, Production and Yield of Rapeseed and Mustard crop in Nagaon district of Assam. Progressive Agricul 12: 392-395.

Dhakre, D. S. and Sharma, A. 2010. Growth Analysis of Area, Production \& Productivity of Maize in Nagaland. Agriculture Sci Digest 30: 142-144.

Hazell, P. B. R. 1985. "Sources of Increased Variability in World Cereal Production since the 1960s." Journal of Agricultural Economics, 36 (2): 145159.

India Maize Summit, 2014.

Lakhera, M. L. 2011. Statistical Package for Analysis of Design of Experiment (SPADE), Dept. of Agril. Statistics and Social Science (L.), IGKV, Raipur.

National conference on rabi campaign C.G., Sept. 2012. 
Sharma, A. 2012. Trends of area, production and productivity of major fruit crops in North Eastern Region of India. Economic Affair. 57: 259-276.

Sharma, A. and Kalita, D. C. 2004. Trends of area, production and productivity of food grain crops in north eastern states. Nagaland University Res. J. 2: 31-37.
Singh, A.K. and Baghel, S.S. 1991-94. Predictive models for the Area, Yield and Production of Rice in Chhattisgarh and its constituent's district along with the influence of Area and Yield on the Production- A different approach. Farm Sci. J.: 6-9.

\section{How to cite this article:}

Pradeep Kumar Ganjeer, Durgesh Sagar, V. Mishra and Lakhera, M.L. 2018. Distribution of Area, Production and Productivity of Maize in Different Districts of Northern Hills of Chhattisgarh, India. Int.J.Curr.Microbiol.App.Sci. 7(08): 2434-2441. doi: https://doi.org/10.20546/ijcmas.2018.708.246 